\title{
Breach of Psychological Contract and Burnout: Is There a Link?
}

\author{
Mariya Razzaghian ${ }^{1}$, Usman Ghani
}

\begin{abstract}
Employees seek out a bilateral relationship when they are employed in an organization. Psychological contracts are one way of seeking this reciprocation which is formed during the pre-employment negotiations. But breach of such contracts may have negative ramifications. This study uses data of the banking sector of Pakistan to find out the level of breaches in the promises made to the employees and to examine whether such breach of psychological contracts is linked to a bankers' job burnout experiences. Data is collected through questionnaires from 6 randomly selected leading banks of Pakistan operating in Peshawar, and analyzed through frequency tables and chi-square test. It is found that $33 \%$ of the bankers believe that their employers have poorly fulfilled their promises. This breach is also associated with exhaustion and depersonalization.
\end{abstract}

Keywords: reciprocation, breach, emotional strain, exchange contract, social support, chi-square tests.

\section{Introduction}

Organizations spend much of their money nowadays over their employees not only to keep a healthy workforce but also to keep the employment relationship intact. However, the job environment has become more volatile lately than they were in the past. This volatility has led to a sense of insecurity in the employees also. This calls for an increased focus on the invisible but important aspects of the employment relationship. By doing so, the employers thus eliminate the sources of employee insecurity. One such aspect is the development of psychological contracts and their fulfillment. Psychological contracts are a type of a promissory contracts (Rousseau \& Parks, 1993) which the organization has to provide to an individual employee as a reciprocation for the latter's contributions in that organization. It has been shown through previous researches that negative outcomes are associated with employees when they feel that their organizations are unable to fulfill their promises (Lambert, Edwards, \& Cable, 2003).

Based on the above perspective, this paper aims to answer the following research questions: 1) what are the promises that are mostly made to the employees (as perceived

1 PhD Scholar, Institute of Management Sciences, Peshawar. Email: moorazz@hotmail.com

2 Assistant Professor, Institute of Management Sciences, Peshawar. Email: usman.ghani@imsciences. edu.pk 
by them) during the pre-employment period? 2) what is the level of breach of these promises? and 3) is the breach in psychological contract associated with the three dimensions of burnout, i.e. emotional exhaustion, depersonalization, or reduced personal accomplishments?

Rest of the paper is organized as follows: Section 2 gives an account of previous literature. Section 3 describes the methodology of the study, followed by analysis and results in Section 4. Section 5 concludes the paper.

\section{Literature Review}

\subsection{Psychological Contracts}

Blau (1954) explained the social exchange theory by stating that "an individual who supplies rewarding services to another obligates him. To discharge this obligation, the second must furnish benefits to the first in turn" (p. 89). Thus, according to this social exchange theory, individuals tend to enter into relationships that are not merely based on economic or monetary aspects. Rather, these relationships consist of more complex obligations or commitments that are deemed as necessary for the individuals. Reciprocation is important in any social exchange as it creates a sense of interdependence and social bond between the individual and his/her employer. However, these obligations are exchanged at different intervals and periods. Different researchers like Gouldner (1960), Homans (1961), and Wayne, Shore, and Liden (1997) believe that individuals prefer to seek a balanced exchange of these obligations. Balanced exchange means that each party in the contract would be responsible for its own side of the bargain only to the extent the other party does so.

Different social exchange models have been used in the literature to determine how employment relationships can be predicted. For example, the relationship of employees with their supervisors (Wayne et al., 1997) or the employees' trust in their managers (Whitener, Brodt, Korsgaard, \& Werner, 1998) etc. Similarly, psychological contracts are also predictors of social exchange models as these contracts also involve (implicit) employment contracts (Rousseau, 1995). Likewise, while determining the employment relationships, equity theory (Adams, 1965; Walster, Walster, \& Berscheid, 1978) states that people tend to appraise and assess their relationships with others on the basis of investments they make and the outcomes that are produced as a result of them. In interpersonal relationships individuals are inclined to seek reciprocity and where they find themselves to be pursuing a relationship which lacks reciprocity, they tend to get distressed (Buunk \& Schaufeli, 1999). Walster et al. (1978) elaborate the equity theory by stating that if the inequity or the lack of reciprocity is larger, the distress felt by such individuals will also be large and they will try even harder to 
restore equity. Thus, reciprocity occurs when an individual's personal investments and outcomes in a relationship are proportionate to the investments and the outcomes of the other party in that relationship (Adams, 1965).

If different characteristics are predictors of social exchange models, then the fulfillment (or breach) of each characteristic is going to have a distinct outcome in that social exchange process. This paper specifically focuses on the psychological contracts and the breach of these contracts. Researchers like Rousseau (1989) and Schein (1980) see psychological contracts as fundamental in understanding why employees behave in a particular manner during their jobs when they do so. Till date, psychological contracts have been, in fact, used in various forms to understand the employment relationships either through the psychological contract fulfillment or its breach (Conway \& Briner, 2002).

Rousseau and Parks (1993) have termed psychological contract as a type of a promissory contract that is essentially an individual level phenomenon. Psychological contract has been defined as "individuals' beliefs, shaped by the organization regarding terms of an exchange agreement between individuals and their organizations" (Rousseau, 1995, p. 9). These beliefs encompass both the implicit and the explicit promises (Robinson, Kraatz, \& Rousseau, 1994) that the organization has to provide to an individual employee as an exchange for the contributions made by the latter in the form of loyalty, efforts, etc. (Conway \& Briner, 2002). Morrison and Robinson (1997) and Shore and Tetrick (1994) explicate that psychological contracts are not only involved in generalized set of expectations but perceived set of promises as well. These promises are the reasons for which employees believe that the expected obligations ought to be fulfilled. But since psychological contracts are implicit in nature, therefore the perceived promises may not always be clearly stated in black and white, and this is the reason why these are termed as perceived promises.

Generally when contracts are formed, they lead to a reduction in uncertainty and an increase in the predictability for the employees in the employment relationship. Although psychological contracts are more person specific, they still serve the initial purpose of reducing uncertainty (Shore \& Tetrick, 1994). Sutton and Kahn (1986) described understanding, predictability and control to be the essential components that would prevent work related stress. Parks (1992), Rousseau (1989), and Rousseau and Parks (1993) have distinguished between two types of psychological contracts: the transactional and the relational contract. The former is more of an exchange contract, whereas the latter is linked to the social exchange. A mandatory point to mention here is that as these contracts are psychological in nature and are formed on part of employees, this is the reason why there are chances that the other party may not be sharing exactly the same expectations (Lucero \& Allen, 1994; Rousseau, 1989). 
Herriot and Pemberton (1996) criticized the existing literature regarding this concept stating that all that has been said about psychological contract so far is more rudimentary. Guest (1998) has critically reviewed the construct of psychological contract and according to him, psychological contract is not a theory or a measure but it is more of a hypothetical construct, as it basically revolves around the interaction between one definite individual and another "nebulous party" (p. 650). He has declared this contract inappropriate because a it actually resides in the eye of the beholder. Therefore, it remains implicit in the minds while the employee expects them to be fulfilled, whereas in reality there is no way of checking them. Thus, the phenomenon of psychological contract lies within the interaction per se that takes place between the two parties, rather than specifically between a specific individual and the organization itself.

\subsubsection{Formation of Psychological Contracts}

The common social norms of reciprocity (Gouldner, 1960) as well as contracting (Rousseau \& Parks, 1993) set the stage for the formation of a psychological contract by the employee which would represent the employment relationship (Shore \& Tetrick, 1994). It is a fact that every individual develops a distinct set of psychological contract and these contracts are formed primarily during the pre-employment negotiation (Dunahee \& Wangler, 1974). The expected set of obligations that organizations are liable to provide to an individual employee and which forms the psychological contract can be developed through observing the procedures of the organization or through the interaction with other organizational actors (Rousseau \& Parks, 1993). Employees may also deduce them from many ways, including the actions of the employer (Rousseau, 2001) or they may believe that promises have been made to them personally. Turnley and Feldman (1999) have put forth three main sources from which the individuals develop psychological contract; first, are those promises that are made to them by the organizational representative (recruiters) usually at the time of employment. Second, from how the individual him/herself perceive the culture of the organization? And last, from what Turnley and Feldman (1999) have referred to as the individual's own set of distinct beliefs and expectation regarding the manner in which the organizations function. Employees then determine if those promises have been kept by matching their experiences with the perceived set of promises (Johnson \& O'Leary-Kelly, 2003).

\subsubsection{Causes of Psychological Contract Violation}

It has been observed that contract violation is on the rise (Guest, 1998) and Robinson and Rousseau (1994) claim this violation to be a norm. Perceptions of psychological contract breach can be experienced by individuals due to various reasons. Breach of psychological contracts occurs when an employee perceives that the employer 
(or the organization) has failed to fulfill its promises or the expectations. Since these contracts have an element of person-specificity (Johnson \& O'Leary-Kelly, 2003), it is likely that an employee and his/her supervisor have different understanding of the psychological contract. Thus, an employee may experience a breach in the fulfillment of this construct at some point whereas the supervisor may not even be aware of the situation his subordinate is going through (Lester, Turnley, Bloodgood, \& Bolino, 2002). Rousseau (1995) and Morrison and Robinson (1997) have highlighted three reasons of why a breach occurs. First, it can occur due to what has been termed as reneging on part of the organization. Reneging means that the organization could have fulfilled its promises made to the individual employees but did not do so willingly due to some self interest of the top management. Second, disruption is also a reason for the breach to occur. Disruption occurs when the management or the organization has no hold over certain factors which occur outside of the organization's control and force the organization either to limit their salaries or to lay-off their employees. This situation occurs in times of economic crisis. Last, there may be a lack of a harmonious understanding between what employees expects from the organization and what the organization is offering them. Interestingly, employees attribute the breach in their psychological contract to reneging (Jones \& Davis, 1965) and are least likely to accept any justifications for it (Shapiro, Buttner, \& Barry, 1994). To some extent the breach is also associated with incongruence between what has been observed by employees during the time of acceptance of the employment contract and how the organization is actually functioning (Lester et al., 2002). Conversely, the organization(s) is (are) more expected to report the breach in contracts to disruption (Shapiro et al., 1994).

Individuals who believe that they have no say or voice in the change process of an organization are the foremost going to experience a breach (Morrison \& Robinson, 1997). Similarly, employees working at the lower levels of the organizational hierarchy are also less likely to be able to connect themselves with the management of the organization and hence, encounter a breach of this contract (Lester et al., 2002).

\subsubsection{Impacts of Breach on Employees}

Owing to the importance of psychological contracts for employees, it can be argued that a breach in this contract will be disapproved by the employees with negative repercussions for them. Morrison and Robinson (1997) have discussed the ramifications of the psychological contract violation as "an affective and emotional experience of disappointment, frustration, anger and resentment that may emanate from an employee's interpretation of a contract breach and its accompanying circumstances" (p. 242). Violation of the psychological contract can occur either at the transactional level or the relational level or both. In cases where transactional 
obligations are violated, it may lead to less intense reactions. However, if long-term relational contracts are violated, the reactions may get more severe (Robinson et al., 1994). It is believed that the breach of a psychological contract can have important consequences for the organization(s) in terms of how employees would react to behave during work. The reason that psychological contracts need to remain intact owes to the important negative outcomes that can arise for the organization in the form of actual turnover, lowered satisfaction and performance, and decrease in citizenship behavior (Robinson, 1996; Robinson \& Rousseau, 1994). Therefore, psychological contracts are the stepping stones for developing perceptions of predictability and control for the employees. In case of any breach in the contract, both predictability and control are decreased (Shore \& Tetrick, 1994). Sutton (1990) associate the decline in the perceptions of predictability and control with stress for such employees. Kozlowski, Chao, Smith, \& Hedlund (1993) also maintain that organizations' failure to fulfill their obligations, which they owe to their employees, may have a negative impact on the latter. These negative effects can be exhibited in the form of experiencing stress during job which produces strain (Maslach, Schaufeli, \& Leiter, 2001), leading to emotional exhaustion and job dissatisfaction (Lee \& Ashforth, 1996). Shore and Tetrick (1994) have summed up employees' reaction to psychological contract in terms of voice, silence, retreat, destruction, and exit.

The discussion on the formation and breach of psychological contracts sets the premise for further developing this construct. This paper aims to add on to this discussion by introducing the construct of burnout during job to check any linkages between the variables of psychological contract breach and feelings of burnout during job.

\subsection{Job Burnout}

Burnout is a syndrome of emotional exhaustion, depersonalization, and lack of personal accomplishments, making it a multi-dimensional construct (Maslach and Jackson, 1985). Shirom (1989) also believes that burnout is a distinctive aspect of stress because it arises in response to the demanding stressors at work which are interpersonal in nature and are a cause of putting strain on the individual. Therefore, the construct of burnout has been declared to be different from other related constructs like general depression etc. due to its multi-dimensionality and the manner in which each stage of burnout evolves into a subsequent one (Maslach \& Schaufeli, 1993).

Emotional exhaustion occurs when individuals feel that they do not have enough emotional resources or energy left to function. The depersonalization dimension of burnout encompasses how individuals respond to others (the recipients of the organization). Those employees who undergo this aspect usually get indifferent, negative minded and get detached either from their work or their recipients. On the other hand, 
the personal accomplishment dimension of burnout refers to how individuals respond to their own self. A lack of personal accomplishment generally means that people feel a reduction in their level of competence and achievement (Maslach, 1993). Emotional exhaustion is believed to be the core dimension of burnout. This can be judged from the fact that when individuals complain of suffering from burnout, they actually tend to experience exhaustion (Maslach et al., 2001). This led Shirom (1989) to argue that the other two components (depersonalization and lack of personal accomplishment) of burnout are rather unnecessary. But this has been criticized by Maslach et al. (2001) who state that excluding these two aspects of burnout and focusing exclusively on emotional exhaustion does not actually paint a true picture of the actual relationship people have with their jobs. They also believe that when individuals reach their point of emotional exhaustion, they tend to distance themselves from the service recipients voluntarily or they adopt cynical attitudes towards their work. The role of the third component of burnout, i.e. reduced or lack of personal accomplishment, has been found to be very complex. In some instances exhaustion and depersonalization or cynicism combine to produce this effect (Byrne, 1994; Lee \& Ashforth, 1996) and at other instances it occurs in parallel to other two components, rather than occurring one after the other (Leiter, 1993).

According to the Conservation of Resources theory (CoR), employees will work hard during their jobs in order to achieve those things which they value the most. These can be termed as resources. However, when the demands on the job exceed the resources or if the resources are completely considered to be unattainable, or do no match up with the demands, an imbalance occurs. This leads to stress among the individuals (Hobfoll \& Freedy, 1993).

In the burnout literature, social support during the job has been considered as a resource for the employees (Janssen, Schaufeli, \& Houkes, 1999). Cohen and Wills (1985) stated that the source (s) of social support during the job has to be something from the same work environment. This is important because it will enable the supporter to understand the intricacies of the job place in the same manner as that of a particular employee requiring support. A lack of social support is a source of burnout for that individual. On the other hand, when employers do not fulfill their part of the psychological contract, the employees perceive that the organization does not care much about the contributions made by them (Eisenberger, Huntington, Hutchison, \& Sowa, 1986).

As stated earlier, psychological contract has been declared as a construct that is person-specific because it refers to how an individual employee tacitly develops a social exchange relationship between him/herself and the employer. Therefore, this psychological contract ought to vary from person to person. In a similar manner, 
burnout has been declared as an individual stress experience which arises as a result of complex social relationships at work (Johnson \& O'Leary-Kelly, 2003). Any employment relationship involves the foremost aspect of personal trust. An individual has to have a trust in the organization that the latter will cater different physiological and psychological needs of the employee when he/she accepts an employment agreement. And according to the psychological contract theory, a breach of this contract is thought off to be a violation of this personal trust (Robinson, 1996). This violation can have severe repercussions in terms of emotional reactions (Morrison \& Robinson, 1997).

\section{Methodology}

\subsection{Target Population}

Banking sector is also one of the most growing and leading sectors of Pakistan. Various studies are conducted on psychological contracts in this sector elsewhere. Cohen (2011) and Rigotti (2009) also tried to test psychological contract in the banking sector of Israel and Germany, respectively. This paper also aims to target the banking sector in Pakistan where not many studies have been done in this regard.

\subsection{Procedure}

A list of leading Pakistani banks (both public and private) operating in Peshawar was obtained from the website of the State Bank of Pakistan. From the population, a total of 6 banks were randomly selected as a sample. In the second stage, $30 \%$ of each bank's branches were randomly selected through the same procedure. The inclusion criteria for banks for the purpose of this research were managers as well as the operational staff. The questionnaires were self-administered and the participants were ensured of the confidentiality as they were anonymous and secondly were collected the next day of administering them.

In total, 289 questionnaires were distributed and the number of questionnaires returned by the respondents was 207 . They were then screened manually and 20 questionnaires were discarded due to improper filling. This made the response rate of the study to be $71.62 \%$.

\subsection{Measurements}

Psychological contract breach: This served as an independent variable of the study. To measure the promises made to the employees, an inventory on psychological contract breach (or fulfillment) which has been developed by Kickul, Lester, \& Finkl (2002) was used. This inventory not only measures the extent to which the promises made to employees have been fulfilled by the employer but also the contents of a 
psychological contract. A list of 26 items was presented to the bankers and they were asked to first indicate which of the items were promised to them. In the next step, they were supposed to indicate the extent to which the promises made have been successful. The responses ranged on a 5-point Likert scale from 'Not at all fulfilled', 'Slightly fulfilled', 'Moderately fulfilled', 'Highly fulfilled' to 'Very highly fulfilled'.

The breach of psychological contract was measured through a single item measure, "please indicate how well, overall, your employer has fulfilled the promised obligations that they made to you? It is developed by Robinson and Rousseau (1994). The responses ranged on a 5-point Likert scale starting from 'Very poorly fulfilled' to 'Very well fulfilled'.

Job burnout: Burnout during job serves as the dependent variable of this study and is measured through the Maslach Burnout Inventory-General Survey (MBI-GS). This is a 22-item inventory developed by Schaufeli, Leiter, Maslach \& Jackson (1996) which taps emotional exhaustion, cynicism or depersonalization and professional efficacy or reduced personal accomplishments (encompassing both social and non social aspects of occupational accomplishments). The responses ranged on a 7-point scale and were: 'Never', 'A few times a year or less', 'Once a month or less', 'A few times a month', 'Once a week', 'A few times a week' and 'Everyday'. The internal consistency of MBI-GS inventory for this study was measured using the reliability analysis. The Cronbach's alpha was found to be 0.85 which is above the minimum threshold of 0.7 as recommended by Nunnally (1978), stating a good level of reliability for the scale used. As for the content validity, experts specialized in Human Resources scrutinized the questionnaire at length.

\section{Results}

To answer the research questions of the study, frequency tables and chi-square tests are used. To answer the first research question, "What are the promises that are mostly made to the employees (as perceived by them) during the pre-employment period?" the responses of the respondents with respect to 26 items are presented in Table 1. It is evident from Table 1 that the item deemed as promised the most from employees' perspective is pay and bonuses based on performance, followed by competitive salary. On the other hand, the least promised item was tuition reimbursement.

To find an answer to the second research question, "what is the level of breaches of these promises?" the respondents were asked to indicate the extent to which they believed their employer had been successful in fulfilling the promises they had made to them, either in writing or verbally (or both) at the time of appointment. The responses are presented in Table 2. From this table it can be observed that the highest 
Table 1: Types of promises made to the employees by the employers

\begin{tabular}{|c|c|c|c|}
\hline S.No & Items & Percentage Promised & $\begin{array}{c}\text { Percentage Not } \\
\text { Promised }\end{array}$ \\
\hline 1. & Pay and bonuses based on performance & $94.7 \%$ & $5.3 \%$ \\
\hline 2. & Competitive salary & $93.6 \%$ & $6.4 \%$ \\
\hline 3. & $\begin{array}{l}\text { Opportunities for promotion and } \\
\text { advancement }\end{array}$ & $89.8 \%$ & $10.2 \%$ \\
\hline 4. & Vacation benefits & $86.1 \%$ & $13.9 \%$ \\
\hline 5. & Continual professional training & $86.1 \%$ & $13.9 \%$ \\
\hline 6. & Opportunities for personal growth & $85.6 \%$ & $14.4 \%$ \\
\hline 7. & Health care benefits & $85.0 \%$ & $15.0 \%$ \\
\hline 8. & Job security & $84.0 \%$ & $16.0 \%$ \\
\hline 9. & Job training & $81.8 \%$ & $18.2 \%$ \\
\hline 10. & Retirement benefits & $80.7 \%$ & $19.3 \%$ \\
\hline 11. & Well-defined job responsibilities & $80.7 \%$ & $19.3 \%$ \\
\hline 12. & Adequate equipment to perform job & $79.7 \%$ & $20.3 \%$ \\
\hline 13. & Opportunity to develop new skills & $79.1 \%$ & $20.9 \%$ \\
\hline 14. & Increasing responsibilities & $79.1 \%$ & $20.9 \%$ \\
\hline 15. & Safe work environment & $78.6 \%$ & $21.4 \%$ \\
\hline 16. & Recognition of accomplishments & $77.5 \%$ & $22.5 \%$ \\
\hline 17. & Enough resources to do the job & $77.0 \%$ & $23.0 \%$ \\
\hline 18. & A reasonable workload & $77.0 \%$ & $23.0 \%$ \\
\hline 19. & Flexible work schedule & $75.9 \%$ & $24.1 \%$ \\
\hline 20. & Challenging and interesting work & $75.9 \%$ & $24.1 \%$ \\
\hline 21. & Freedom to be creative & $74.3 \%$ & $25.7 \%$ \\
\hline 22. & Meaningful work & $72.2 \%$ & $27.8 \%$ \\
\hline 23. & Participation in decision making & $72.2 \%$ & $27.8 \%$ \\
\hline 24. & Career guidance and mentoring & $71.1 \%$ & $28.9 \%$ \\
\hline 25. & $\begin{array}{l}\text { A job that provides autonomy and } \\
\text { control }\end{array}$ & $69.0 \%$ & $31.0 \%$ \\
\hline 26. & Tuition reimbursement & $66.3 \%$ & $33.7 \%$ \\
\hline
\end{tabular}

percentage of employees were neutral (45.9\%) regarding their belief about how well they found their employer to be successful in fulfilling their promises. On the other hand, $33.7 \%$ of the respondents believed that their employers had either very poorly fulfilled or poorly fulfilled what they had promised. 
Table 2: Frequency of the overall level of psychological contract breach

\begin{tabular}{|c|c|c|}
\hline S.No & Extent of breach & Response percentage \\
\hline 1. & Very poorly fulfilled & $10.2 \%$ \\
\hline 2. & Poorly fulfilled & $23.5 \%$ \\
\hline 3. & Neutral & $45.5 \%$ \\
\hline 4. & Well fulfilled & $20.9 \%$ \\
\hline 5. & Very well fulfilled & $0 \%$ \\
\hline
\end{tabular}

To find an answer to the third research question, "Is the breach in the psychological contract associated with the three dimensions of burnout, which are emotional exhaustion, depersonalization and reduced personal accomplishments?" the respondents were asked to indicate the extent to which they experienced burnout during their job due to the breach of the employment contract. They were asked to specify their burnout levels across the three dimensions of burnout which are emotional exhaustion, depersonalization and reduced personal accomplishments (or reduced efficacy). The following tables show results for each dimension respectively.

Table 3: Association of overall level of psychological contract breach with emotional exhaustion (dimension of burnout)

\begin{tabular}{|c|c|c|c|c|c|}
\hline \multicolumn{2}{|c|}{ Psychological contract breach } & \multicolumn{3}{|c|}{ Emotional Exhaustion } & \multirow[t]{2}{*}{ Significance } \\
\hline & & Low & Moderate & High & \\
\hline \multirow{5}{*}{$\begin{array}{l}\text { How well, overall, } \\
\text { your employer has } \\
\text { fulfilled the prom- } \\
\text { ised obligations that } \\
\text { they made to you? }\end{array}$} & $\begin{array}{l}\text { Very poorly } \\
\text { fulfilled }\end{array}$ & $10.5 \%$ & $26.3 \%$ & $63.2 \%$ & \\
\hline & Poorly fulfilled & $27.3 \%$ & $43.2 \%$ & $29.5 \%$ & \\
\hline & Neutral & $48.2 \%$ & $29.4 \%$ & $22.4 \%$ & \\
\hline & Well fulfilled & $69.2 \%$ & $20.5 \%$ & $10.3 \%$ & \\
\hline & Very well fulfilled & $0 \%$ & $0 \%$ & $0 \%$ & \\
\hline Chi-square & 32.045 & & & & 0.000 \\
\hline Df & 6 & & & & \\
\hline
\end{tabular}

Table 3 shows the value of chi-square statistic to be 32.045 which is greater than the critical value at $6 \mathrm{df}$, i.e. 12.59 . Similarly, the p-value is less than the level of significance (0.05), thus rejecting the null hypothesis. This shows that the relationship between psychological contract breach and emotional exhaustion dimension of burnout is highly significant. Also, those who felt that their employer had very poorly fulfilled their promises made to them felt the highest level of emotional exhaustion (63.2\%). 
Table 4: Association of overall level of psychological contract breach with depersonalization (dimension of burnout)

\begin{tabular}{|c|c|c|c|c|c|}
\hline \multicolumn{2}{|c|}{ Psychological contract breach } & \multicolumn{3}{|c|}{ Depersonalization } & \multirow[t]{2}{*}{ Significance } \\
\hline \multirow{5}{*}{$\begin{array}{l}\text { How well, overall, } \\
\text { your employer has } \\
\text { fulfilled the prom- } \\
\text { ised obligations that } \\
\text { they made to you? }\end{array}$} & $\begin{array}{l}\text { Very poorly } \\
\text { fulfilled }\end{array}$ & $26.3 \%$ & $36.8 \%$ & $36.8 \%$ & \\
\hline & Poorly fulfilled & $29.5 \%$ & $22.7 \%$ & $47.7 \%$ & \\
\hline & Neutral & $44.7 \%$ & $24.7 \%$ & $30.6 \%$ & \\
\hline & Well fulfilled & $61.5 \%$ & $15.4 \%$ & $23.1 \%$ & \\
\hline & Very well fulfilled & $0 \%$ & $0 \%$ & $0 \%$ & \\
\hline Chi-square & 13.056 & & & & 0.042 \\
\hline Df & 6 & & & & \\
\hline
\end{tabular}

Similarly, those employees who believed that their employers had well fulfilled their promised obligations felt the lowest level of emotional exhaustion (69.2\%).

Table 4 shows the value of chi-square statistic to be 13.056 which is greater than the critical value at $6 \mathrm{df}$, i.e. 12.59. Similarly, the p-value is less than the level of significance (0.05), thus rejecting the null hypothesis. This shows that there exists a significant relationship between psychological contract breach and the depersonalization dimension of burnout. Those respondents who found their employer to have very poorly fulfilled his promises equally experienced moderate to high depersonalization

Table 5: Association of overall level of psychological contract breach with reduced personal accomplishment (dimension of burnout)

\begin{tabular}{|c|c|c|c|c|c|}
\hline \multicolumn{2}{|c|}{ Psychological contract breach } & \multicolumn{3}{|c|}{ Reduced personal accomplishment } & \multirow{3}{*}{ Significance } \\
\hline & & Low & Moderate & High & \\
\hline \multirow{5}{*}{$\begin{array}{l}\text { How well, overall, } \\
\text { your employer has } \\
\text { fulfilled the prom- } \\
\text { ised obligations that } \\
\text { they made to you? }\end{array}$} & $\begin{array}{l}\text { Very poorly } \\
\text { fulfilled }\end{array}$ & $10.5 \%$ & $26.3 \%$ & $63.2 \%$ & \\
\hline & Poorly fulfilled & $27.3 \%$ & $43.2 \%$ & $29.5 \%$ & \\
\hline & Neutral & $48.2 \%$ & $29.4 \%$ & $22.4 \%$ & \\
\hline & Well fulfilled & $69.2 \%$ & $20.5 \%$ & $10.3 \%$ & \\
\hline & Very well fulfilled & $0 \%$ & $0 \%$ & $0 \%$ & \\
\hline Chi-square & 4.557 & & & & 0.602 \\
\hline Df & 6 & & & & \\
\hline
\end{tabular}


(36.8\%, respectively). On the contrary, low level of depersonalization was experienced by those who considered their employers as committed to fulfilling their promises.

Table 5 shows the value of chi-square statistic to be 4.557 which is less than the critical value at $6 \mathrm{df}$, i.e. 12.59. Similarly, the p-value is greater than the level of significance (0.05), thus confirming the null hypothesis. This means that the third dimension of burnout, i.e. reduced personal accomplishments, showed no significant relationship with psychological contract breach. In other words, perceptions of breach of psychological contracts had no effect on the experience of this burnout in terms of reduced personal accomplishments. However, it can be seen from the findings presented in the table above that when respondents believed that psychological contract was very poorly fulfilled, the reduction in personal accomplishment was high and when the contract was well fulfilled, the experience of reduced personal accomplishment was low.

\section{Conclusion}

The results from this study have revealed that employees do believe that their employers are not doing a good job as far as fulfilling the promises which they had made to the employees (either verbally or in writing or both) is concerned. Consequently, employees feel emotionally exhausted (the first dimension of burnout) and experience depersonalization or cynicism during their jobs. However, the levels of emotional exhaustion felt and depersonalization experienced is dependent on the extent to which the employees feel that the breach has occurred. The association of psychological contract breach with the feelings of exhaustion is also supported by earlier work. For example, Gakovic and Tetrick (2003) have also revealed that breach in psychological contract is a potential source of employee reports of emotional exhaustion. Similarly, in a meta-analysis conducted by Chiaburu, Peng, Oh, Banks, and Lomeli (2013), the findings were indicative of the fact that psychological contract violation was strongly related to organizational cynicism/depersonalization.

Another important and worth mentioning finding of this study is that breach of psychological contract was not significantly associated with reduced efficacy or reduced personal accomplishment dimension of burnout. In other words it can be said that employees' perception of breach in their psychological contracts is a source of emotional strain for them which leads to emotional exhaustion (see also Morrison \& Robinson, 1997; Lee \& Ashforth, 1996), which in turn causes them to be detached from their work and experience depersonalization. This finding also strengthens the argument of Maslach et al. (2001) which refers to emotional exhaustion as the core component of burnout and upon reaching this point, employees start to adopt a cynical attitude towards their work. 
Hence to summarize, the results of this study show that employees perceive breach in the promises made by their employers. This breach is associated with emotional exhaustion and feelings of depersonalization but not with the feelings of reduced personal accomplishments. In today's dynamic and volatile job environment, it is imperative that the employers convey realistically what they shall be providing to their employees as reciprocation for their services. The findings from this study contribute to the stress literature by discussing the employment relationship perceptions and the stress process in Peshawar (Pakistan).

This study was conducted in order to exclusively determine the bankers' (employees) perspective of the level of breach regarding the items promised to them by their employers. Therefore, future researches can be carried out to know if there occurs any breach within the banking sector from the employer's perspective. Second, a comparative study at the transactional level of psychological contract breach versus the relational level can also be conducted in order to find out the level of burnout faced by employees.

\section{References}

Adams, J. S. (1965). Inequity in social exchange. In L. Berkowitz (Eds.), Advances in Experimental Social Psychology, 2. (pp. 267-299), New York: Academic Press.

Blau, P. M. (1964). Exchange and power in social life. New York: Wiley.

Buunk, B. P. and Schaufeli, W. B. (1999). Reciprocity in interpersonal relationships: An evolutionary perspective on its importance for health and well-being. European Review of Social Psychology, 10(1), 259-291.

Byrne, B. M. (1994). Burnout: Testing for the validity, replication, and invariance of causal structure across elementary, intermediate, and secondary teachers. American Educational Research Journal, 31(3), 645-73.

Chiaburu, D.S., Peng, A. C., Oh, I., Banks, G.C., \& Lomeli, L.C. (2013). Antecedents and consequences of employee organizational cynicism: A meta-analysis. Journal of Vocational Behavior, 83(2), 181-197.

Cohen, S., \& Wills, T. A. (1985). Stress, social support, and the buffering hypothesis. Psychological Bulletin, 98(2), 310-357.

Cohen. A. (2011). Values and psychological contracts in their relationship to commitment in the workplace. Career Development International, 16(7), 646-667.

Conway, N., \& Briner, R. B. (2002). Full-time versus part-time employees: Understanding the Links between work status, the psychological contract, and attitudes. Journal of Vocational Behavior, 61(2), 279-301. 
Dunahee, M. H., \& Wangler, L. A. (1974). The psychological contract: A conceptual structure for management / employee relations. The Personnel Journal, 53(7), 518- 526.

Eisenberger, R., Huntington, R., Hutchison, S., \& Sowa, D. (1986). Perceived organizational support. Journal of Applied Psychology, 71(3), 500-507.

Gakovic, A., \& Tetrick, L. E. (2003). Psychological contract breach as a source of strain for employees. Journal of Business and Psychology, 18(2), 235-246.

Gouldner, A. W. (1960). The norm of reciprocity: A preliminary statement. American Sociological Review, 25(2), 161-178.

Guest, D. E. (1998). Is the psychological contract worth taking seriously? Journal of Organizational Behavior, 19(1), 649-664.

Herriot, P., \& Pemberton, C. (1996). Contracting careers. Human Relations, 49(6), 759-790.

Hobfoll, S. E., \& Freedy, J. (1993). Conservation of resources: A general stress theory applied to burnout. In W. B. Schaufeli, C. Maslach, \& T. Marek (Eds.), Professional burnout. Recent Developments in Theory and Research (pp. 115-129). Washington, DC: Taylor \& Francis.

Homans, G. C. (1961). Social behavior: Its elementary forms. New York: Harcourt, Brace, \& World.

Janssen, P. P. M., Schaufeli, W. B., \& Houkes, I. (1999). Work-related and individual determinants of the three burnout dimensions. Work $\mathcal{E}$ Stress, 13(1), 74-86.

Johnson, J. L., \& O'Leary-Kelly, A. M. (2003). The effects of psychological contract breach and organizational cynicism: Not all social exchange violations are created equal. Journal of Organizational Behavior, 24(5), 627-647.

Jones, E. E., \& Davis, K. E. (1965). From acts to dispositions: The attributions process in person perception. In L. Berkowitz (Ed.), Advances in Experimental Social Psychology (Vol. 2, pp.220-266). New York: Academic Press.

Kickul, J. R., Lester, S. W., \& Finkl, J. (2002). Promise breaking during radical organizational change: Do justice interventions make a difference? Journal of Organizational Behavior, 23(4), 469-488.

Kozlowski, S. W. J., Chao, G. T., Smith, E. M., \& Hedlund, J. (1993). Organizational downsizing: Strategies, interventions, and research implications. In C.L. Cooper and I.T Robertson (Eds.), International Review of Industrial and Organizational Psychology (pp. 263-332).

Lambert, L. S., Edwards, J. R., \& Cable, D. M. (2003). Breach and fulfillment of the psychological contract: A comparison of traditional and expanded views. Personnel Psychology, 56(4), 895934.

Lee, R. T., \& Ashforth, B. E. (1996). A meta-analytic examination of the correlates of the three dimensions of job burnout. Journal of Applied Psychology, 81(2), 123-133. 
Leiter, M. P. (1993). Burnout as a developmental process: Consideration of models. In W. B. Schaufeli, C. Maslach, \& T. Marek (Eds.), Professional Burnout: Recent Developments in Theory and Research (pp. 237-250) Washington, DC: Taylor \& Francis.

Lester, S. W., Turnley, W. H., Bloodgood, J. M., \& Bolino, M. C. (2002). Not Seeing Eye to eye: Differences in supervisor and subordinate perceptions of and attributions for psychological contract breach. Journal of Organizational Behavior, 23(1), 39-56.

Lucero, M. A., \& Allen, R. A. (1994). Employee benefits: A growing source of psychological contract violations. Human Resource Management, 33(3), 425-446.

Maslach, C. (1993). Burnout: A multidimensional perspective. In W. B. Schaufeli, C. Maslach, \& T. Marek (Eds.), Professional burnout: Recent developments in theory and research (pp. 19- 32). New York: Taylor \& Francis.

Maslach, C., \& Jackson, S. E. (1985). The role of sex and family variables in burnout. Sex Roles, 12(7-8), 837-851.

Maslach, C., \& Schaufeli, W. B. (1993). Historical and conceptual development of burnout. In W. B. Schaufeli, C. Maslach, \& T. Marek (Eds.), Professional burnout: Recent developments in theory and research (pp. 1-16). Washington DC: Taylor \& Francis.

Maslach, C., Schaufeli, W. B., \& Leiter, M. P. (2001). Job burnout. Annual Review of Psychology, 52(1), 397- 422.

Morrison, E. W. \& Robinson, S. L. (1997). When employees feel betrayed: A model of how psychological contract violation develops. Academy of Management Review, 22(1), 226-256.

Nunnally, J. C. (1978). Psychometric theory. (2nd ed.). New York: McGraw-Hill.

Parks, J. M. (1992). The role of incomplete contracts and their governance in delinquency, in-role and extra-role behaviors. Paper presented at the Society for Industrial and Organizational Psychology, Montreal.

Porter, L. W., Pearce, J. L., Tripoli, A. M., \& Lewis, K. M. (1998). Differential perceptions of employers' inducements: Implications for psychological contracts. Journal of Organizational Behavior, 19, 769-782.

Rigotti, T. (2009). Enough is enough? Threshold models for the relationship between psychological contract breach and job-related attitudes. European Journal of Work and Organizational Psychology, 18(4), 442-463.

Robinson, S. L. (1995). Violation of psychological contracts: Impact on employee attitudes. In L. E. Tetrick and J. Barling (Eds.), Changing Employment Relations: Behavioral and Social Perspectives (pp. 91-108). Washington DC: American Psychological Association.

Robinson, S. L., \& Rousseau, D. M. (1994). Violating the psychological contract: Not the exception but the norm. Journal of Organizational Behavior, 15(3), 245-259. 
Robinson, S. L., Kraatz, M. S., \& Rousseau, D. M. (1994). Changing obligations and the psychological contract: A longitudinal study. Academy of Management Journal, 37(1), 137-152.

Rousseau, D. M. (1989). Psychological and implied contracts in organizations. Employee Responsibilities and Rights Journal, 2(2), 121-139.

Rousseau, D. M. (1995). Psychological contracts in organizations: Understanding written and unwritten agreements. Thousand Oaks, CA: Sage Publications.

Rousseau, D. M. (2001). Schema, promise, and mutuality: The building blocks of the psychological contract. Journal of Occupational and Organizational Psychology, 74(4), 511-541.

Rousseau, D. M., \& Parks, J. (1993). The psychological contracts of individuals and organizations. In L. L. Cummings and B. M. Staw (Eds.), Research in Organizational Behavior (Vol. 15, pp. 1-43). Greenwich, CT: JAI Press.

Schaufeli, W. B., Leiter, M. P., Maslach, C., \& Jackson, S. E. (1996). Maslach Burnout InventoryGeneral Survey. In C. Maslach, S. E. Jackson, \& M. P Leiter (Eds.), The Maslach Burnout Inventory-Test Manual ( $3^{\text {rd }}$ ed.) Palo, Alto, CA: Consulting Psychologists Press.

Schein, E. H. (1980). Organizational psychology. Englewood Cliffs, NJ: Prentice Hall.

Shapiro, D. L., Buttner, E. H., \& Barry, B. (1994). Explanations: What factors enhance their perceived adequacy? Organizational Behavior and Human Decision Processes, 58(3), 346- 368.

Shirom, A. (1989). Burnout in work organizations. In C. L. Cooper \& I. Robertson (Eds.), International review of industrial and organizational psychology. (pp. 25-48). New York: Wiley.

Shore, L. M., \& Tetrick, L. E. (1994). The psychological contract as an explanatory frame work in the employment relationship. In C. L. Cooper and D. M. Rousseau (Eds.), Trends in Organizational Behavior (pp. 91-109). John Wiley \& Sons Ltd.

Sutton, R. I. (1990). Organizational decline process: A social psychological perspective. Research in Organizational Behavior, 12, 205-253.

Sutton, R. I., \& Kahn, R. L. (1986). Prediction, understanding and control as antidotes to organizational stress. In J. Lorsch (Ed.), Handbook of Organizational Behavior. Englewood Cliffs, NJ: Prentice Hall.

Turnley, W. H., \& Feldman, D. C. (1999). A discrepancy model of psychological contract violations. Human Resource Management Review, 9(3), 1-20.

Walster, E., Walster, G. W. \& Berscheid, E. (1978). Equity: Theory and Research. Boston: Allyn \& Bacon.

Wayne, S. J., Shore, L. M., \& Liden, R. C. (1997). Perceived organizational support and leadermember exchange: A social exchange perspective. Academy of Management Journal, 40(1), 82-111.

Whitener, E. M., Brodt, S. E., Korsgaard, M. A., \& Werner, J. M. (1998). Managers as initiators of trust: An exchange relationship framework for understanding managerial trustworthy behavior. Academy 
of Management Review, 23(3), 513-530.

\section{Appendix: Research Questionnaire}

\section{Dear Participant,}

This questionnaire is designed to study the occurrence of burnout among the individual employees. The information you provide will help the researcher to better assess the gravity of this problem and is aimed solely for academic purpose. A strict confidentiality will be maintained for all the information provided. An honest feedback and your cooperation will be appreciated. Thanking you for your time and co-operation.

Please tick the box that you consider true for each statement. Gender:

\begin{tabular}{|c|c|c|c|c|c|c|c|c|}
\hline S.No & Items & Never & $\begin{array}{l}\text { A few } \\
\text { times a } \\
\text { year or } \\
\text { less }\end{array}$ & $\begin{array}{l}\text { Once a } \\
\text { month } \\
\text { or less }\end{array}$ & $\begin{array}{l}\text { A few } \\
\text { times a } \\
\text { month }\end{array}$ & $\begin{array}{c}\text { Once } \\
\text { a } \\
\text { week }\end{array}$ & $\begin{array}{c}\text { A few } \\
\text { times a } \\
\text { week }\end{array}$ & Every \\
\hline 1 & $\begin{array}{l}\text { I feel fatigued } \\
\text { when I get up } \\
\text { in the morning } \\
\text { and have to face } \\
\text { another day on } \\
\text { the job }\end{array}$ & day & & & & & & \\
\hline 2 & $\begin{array}{c}\text { Working with } \\
\text { people all day } \\
\text { is really a strain } \\
\text { for me }\end{array}$ & & & & & & & \\
\hline 3 & $\begin{array}{l}\text { I feel used up at } \\
\text { the end of the } \\
\text { work day }\end{array}$ & & & & & & & \\
\hline 4 & $\begin{array}{l}\text { I feel frustrated } \\
\text { by my job }\end{array}$ & & & & & & & \\
\hline 5 & $\begin{array}{l}\text { I feel burned out } \\
\text { from my work }\end{array}$ & & & & & & & \\
\hline 6 & $\begin{array}{l}\text { I feel I'm work- } \\
\text { ing too hard on } \\
\text { my job }\end{array}$ & & & & & & & \\
\hline 7 & $\begin{array}{c}\text { Working directly } \\
\text { with people puts } \\
\text { too much stress } \\
\text { on me }\end{array}$ & & & & & & & \\
\hline
\end{tabular}




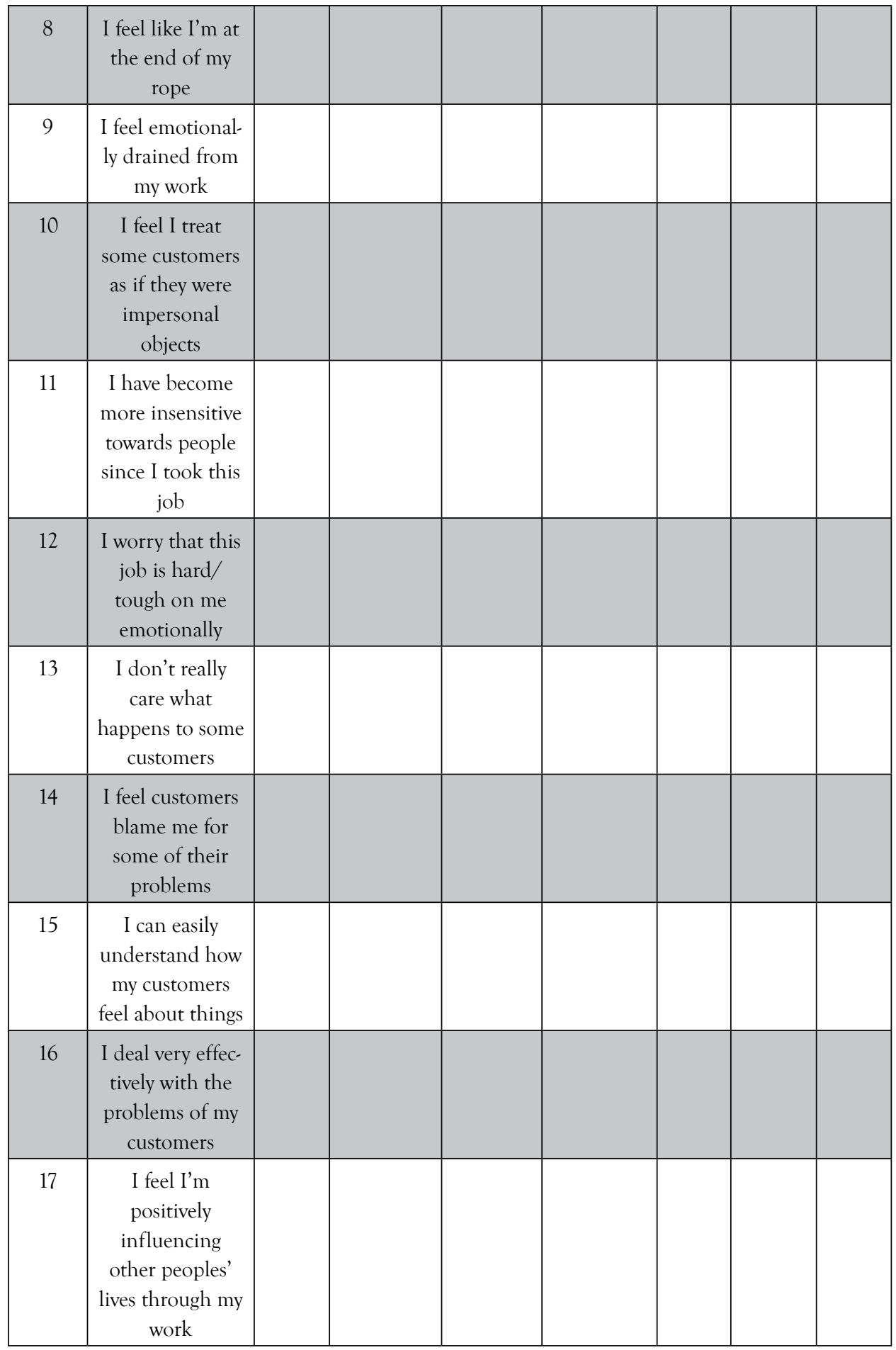




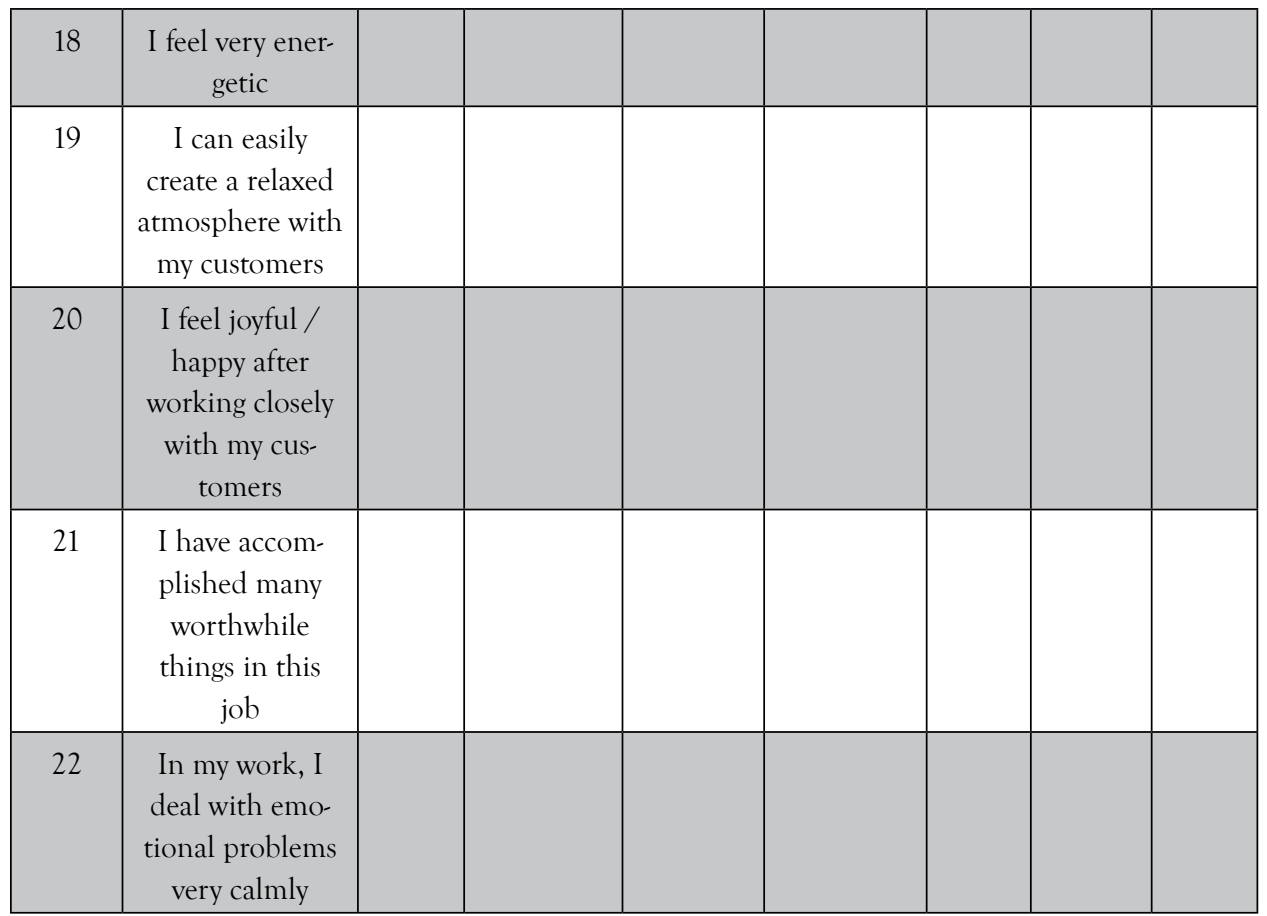

Please note: In the following questions, we are interested to know what you believe your organization has promised to provide to you. Please place ' $\mathrm{X}$ ' in the first column for those promises that your organization has communicated to you either verbally or in writing at the time of appointment.

Then indicate the extent to which your employer has fulfilled those promises by choosing an option from the options given in front of each promise.

\begin{tabular}{|c|c|c|c|c|c|c|}
\hline $\begin{array}{c}\text { Put ' } \mathrm{X} \text { ' } \\
\text { here }\end{array}$ & Promises made to you & $\begin{array}{c}\text { Not at all } \\
\text { fulfilled } \\
(1)\end{array}$ & $\begin{array}{c}\text { Slightly } \\
\text { fulfilled } \\
(2)\end{array}$ & $\begin{array}{c}\text { Moderate- } \\
\text { ly fulfilled } \\
(3)\end{array}$ & $\begin{array}{c}\text { Highly } \\
\text { fulfilled } \\
\text { (4) }\end{array}$ & $\begin{array}{c}\text { Very high- } \\
\text { ly fulfilled } \\
\text { (5) }\end{array}$ \\
\hline & Competitive salary & & & & & \\
\hline & $\begin{array}{c}\text { Pay and bonuses based } \\
\text { on performance }\end{array}$ & & & & & \\
\hline & Vacation benefits & & & & & \\
\hline & Retirement benefits & & & & & \\
\hline & Health care benefits & & & & & \\
\hline & Job security & & & & & \\
\hline & Flexible work schedule & & & & & \\
\hline
\end{tabular}




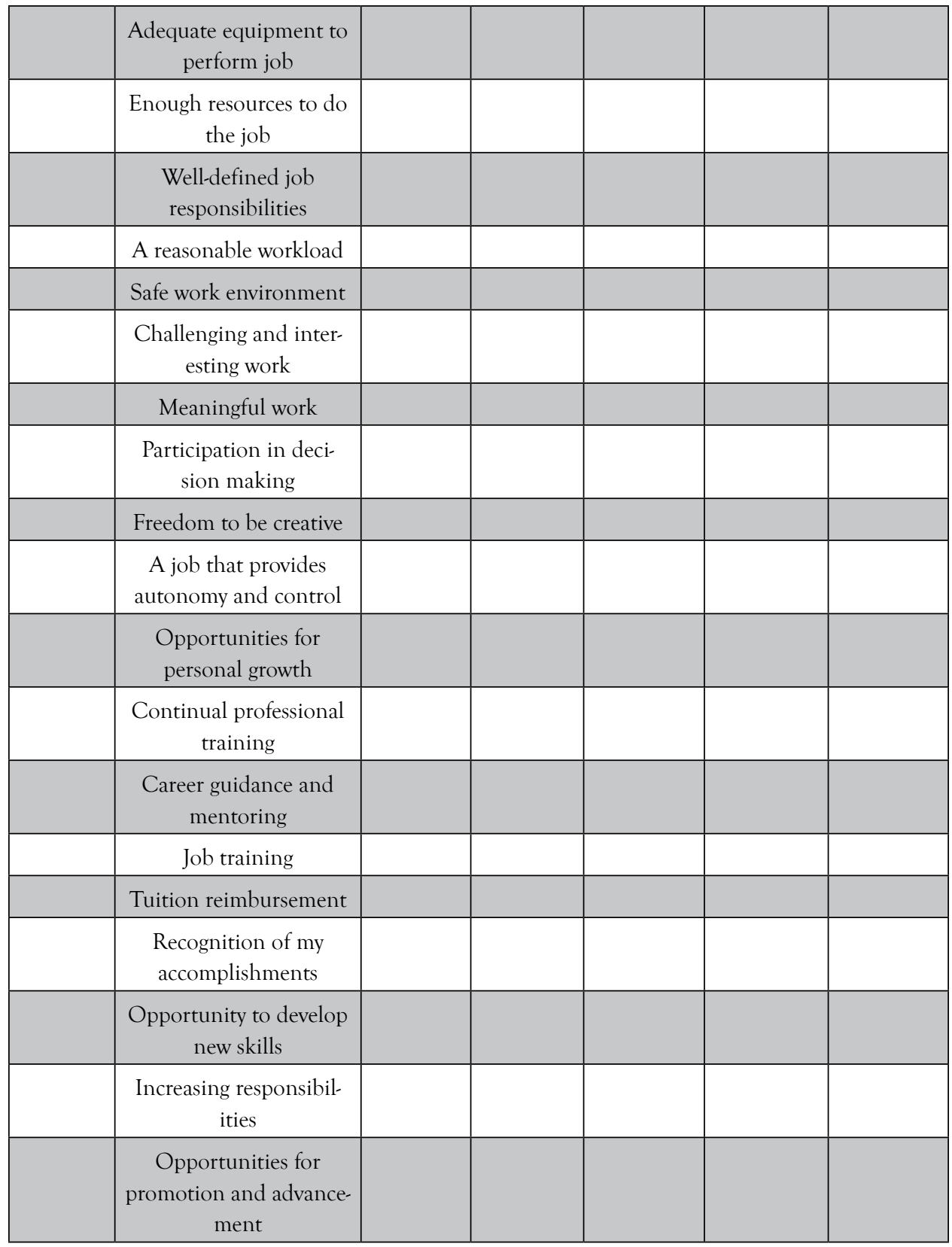

1. Please indicate how well, overall, your employer has fulfilled the promised obligations that they made to you (tick one number only).

\begin{tabular}{|c|c|c|c|c|}
\hline $\begin{array}{c}\text { Very poorly } \\
\text { fulfilled (1) }\end{array}$ & $\begin{array}{c}\text { Poorly fulfilled } \\
(2)\end{array}$ & Neutral (3) & Well fulfilled (4) & $\begin{array}{c}\text { Very well fulfilled } \\
(5)\end{array}$ \\
\hline
\end{tabular}


